


\title{
Suriyeli öğrencilere yönelik Türkçe öğretiminde materyal kullanımı
}

Nurşat BİÇER ${ }^{1}$

Sezgin DEMIR ${ }^{2}$

\begin{abstract}
APA: Biçer, N; Demir, S. (2020). Suriyeli öğrencilere yönelik Türkçe öğretiminde materyal kullanımı. RumeliDE Dil ve Edebiyat Araştırmaları Dergisi, (19), 1-19. DOI: 10.29000/rumelide.751949.
\end{abstract}

\section{Öz}

Türkiye'de yaşayan Suriyeli öğrencilerin eğitim ve öğretimlerini devam ettirebilmelerinde oldukça önemli olan Türkçe derslerinin etkili ve kalıcı olmasında materyaller büyük rol üstlenirler. Kullanılan materyallerin öğrenciye uygunluğu, pratikliği, çoklu öğrenmeye uygunluğu, kültür aktarımını sağlaması, temel dil becerilerini geliştirmesi beklenmektedir. Beklenen bu niteliklerin sağlanmasında da öğretmen önemlidir. Bu çalışmada Suriyeli öğrencilere Türkçe öğreten öğretmenlerin materyal hazırlama, geliştirme ve kullanma durumlarına ilişkin görüşlerinin belirlenmesi amaçlanmıştır. Bu amaç doğrultusunda öğretmenlerden görüş alınarak materyallerin Türkçe öğretimine yansımaları ortaya konmuştur. Çalışmada nitel araştırma desenlerinden olgubilim kullanılmıştır. Çalışma, amaçlı örneklem yöntemiyle belirlenen Kilis ilinde Suriyelilere Türkçe öğreten 11 öğretmenle yürütülmüştür. Veri toplamak için yarı-yapılandırılmış görüşme yöntemiyle gerçekleștirilen görüşmeler ses kayıt cihazıyla kaydedilmiş, bilgisayar ortamında yazılı hâle getirilmiştir. Verileri analizinde içerik analiziyle betimsel analiz birlikte kullanılmış, yapılan analizin güvenilirliği için iki kodlayıcı veriler üzerinde çalışmıştır. Çalışmanın sonuçları değerlendirildiğinde öğrencinin ve öğretmenin olumlu düşüncelerine karşllı süreçte önemli eksikliklerinin olduğu belirlenmiştir.

Anahtar kelimeler: Türkçe öğretimi, materyal, Suriyeli, mülteci, iki dillilik

\section{Use of materials in Turkish teaching for Syrian students}

\begin{abstract}
Materials are playing a major role in Turkish courses for Syrian students refugees in Turkey to continue their education and training. It is expected that the materials used will develop basic language skills so that student adaptability, practicality, suitability for multiple learning, culture transference. Teacher factor is also involved in ensuring these qualities expected from the self. In this study, it was aimed to determine the opinions of the teachers teaching Turkish to the Syrian students about their material preparation, development and use situations. For this purpose, the opinions of the teachers were taken into consideration and the reflections of the materials in Turkish teaching were determined. This research was prepared and carried out according to a phenomenological approach, which is concerned with qualitative patterns. The study was carried out in Kilis with 11 teachers teaching Turkish to Syria. A purposeful sampling method was used for the selection of these teachers. Semi-structured interview method was used to collect data from the

$1 \quad$ Doç. Dr., Kilis 7 Aralık Üniversitesi, Muallim Rıfat Eğitim Fakültesi, Türkçe ve Sosyal Bilgiler Bölümü, Türkçe Eğitimi ABD (Kilis, Türkiye), nursatbicer@gmail.com, ORCID ID: 00oo-0003-3680-7052 [Makale kayıt tarihi: 30.12.2019kabul tarihi: 20.06.2020; DOI: 10.29000/rumelide.751949]

2 Doç. Dr., Frrat Üniversitesi, Eğitim Fakültesi, Türkçe ve Sosyal Bilgiler Bölümü, Türkçe Eğitimi ABD (Elazı̆̆, Türkiye), sezgindemir44@gmail.com, ORCID ID: 0000-0002-0466-2218


teachers and interviews were recorded with voice recorder. This collected data has been written on the computer. Content analysis and descriptive analysis were used together to analyze this data. As a result of the work, teachers and students attach importance to materials; but it has been determined that various problems have been experienced in the process.

Keywords: Teaching Turkish, material, Syrian, refugee, bilingualism

\section{Giriş}

Öğrenme sürecinde öğrencilerin sınıf içerisinde daha etkin olmaları öğrenme başarıları için gereklidir. Öğrencilerin sınıftaki etkinliğini artırma ve sürece daha fazla katılımlarını sağlamada öğrenme materyallerinin önemli bir yeri vardır. Bilgiyi öğrenciye ulaştıran yol ve yöntemler (Heinich vd., 1993) olarak tanımlanan öğretim materyalleri; öğrencinin öğrenme ihtiyaçlarını karşıladığı gibi dikkat çekme, kalıcılık, somutlaştırma ve aktif öğrenmeyi de sağlamaktadır (Yalın, 2003; Karamustafaoğlu vd., 2012). Materyal kullanımı, öğrenme süreçlerinde daha fazla duyunun aktif olmasına firsat vererek çoklu öğrenmeyi mümkün kılmakta ve böylece soyut kavramları somut, anlaşılır kavramlara dönüştürmektedir (Duman, 2013). Kalıcı öğrenmenin gerçekleşmesi için daha çok duyu organına hitap eden ve işitsel araçlarla donatılmış öğrenme ortamları (Dursun, 2006) öğrenme sürecinin vazgeçilemez bir parçasıdır. Eğitimde materyal kullanımı, etkili bir öğrenme ortamı hazırlayarak öğrencilerin öngörülen hedeflere ulaşmalarında ve programın başarıya ulaşmasında önemli bir rol üstlenir (Karamustafaoğlu, 2006: 92). Bu nedenle öğretim materyalleri öğretim programlarıyla uyumlu bir şekilde hazırlanmalıdır (Kaya, 2006). Böylece programda belirlenen kazanımlara erişim sağlanmaya çalışılır. Değişen ve gelişen programlarla beraber kullanılan materyallerde de değişimler söz konusudur. Üç boyutlu materyaller yerine dijital materyallerin kullanımı daha çok rağbet görmeye başlamıştır.

Yaşanan teknolojik gelişmeler sayesinde, eğitim uygulamalarına yeni materyaller eklenerek eğitim ortamları daha da zenginleştirilmektedir. Eğitim-öğretim faaliyetlerinde, yaygınlaşan teknolojiyle bağlantılı araç ve gereçlerin kullanımı (Bektaş vd., 2009) öğrenme ortamında etkileşimi artırmıştır. Şahin ve Gençtürk (2007) günümüzdeki teknolojik gelişmelerin takip edilerek öğretim ortamında aktif öğrenmeyi sağlayacak materyallerin kullanılması gerektiğini belirtirler. Öğrencilerin öğrendiklerini daha fazla hatırlayabilmeleri için etkileşimin sağlandığı çok ortamlı öğrenme durumunun geliştirilmesi ve süreçte kullanılması önem taşımaktadır (Önal vd., 2017). Öğrenme ortamında eğitim sistemi ve teknolojideki değişiklikler, var olan materyallerin yanında materyal geliştirme ve tasarlamayı da önemli bir uğraş alanına dönüştürmüştür (Baki ve Karakuş, 2012: 13). Öğrenme durumlarına bağlı olarak ihtiyaç duyulan materyaller öğretmenler tarafından hazırlanabilmelidir.

Materyallerin kullanımı ve hazırlanması belirli düzeyde bilgi ve beceriyi gerektirdiği (Yalın, 2003) için öğretmen olacak kişilerin yetiştirilmeleri sırasında temel bilgisayar okur-yazarlığı, internet ve öğretim materyalleri hazırlama konusunda eğitim almaları (Halis, 2001: 114) sağlanmalıdır. Öğretmenler, klasik eğitim araç ve gereçlerinin yanında eğitsel video ve sanal ortam yazılımları gibi materyalleri de kullanabilmelidir (Tor ve Erden, 2004). Günümüz eğitiminde farklı roller üstlenmiş olan öğretmenin, hem teknolojiyi kullanması hem de teknolojiyle öğrencinin etkileşimini gerçekleştirmesi beklenmektedir (Kurtdede Fidan, 2008: 49). Eğitim materyalleri kullanma ve hazırlama becerisinin bir anlam ifade etmesi için öğretmenler bunların gerekliliğine inanmalıdır. Eğer öğretmen materyallerin faydasına inanmıyorsa onları kullanmak istemeyecektir (Yalın, 2003). Kullandığı zamanlarda da zorunluluk olarak algılayıp öğrencilerin etkileşimini pek fazla önemsemeyecektir. Bu 
bağlamda öncelikle öğretmenleri eğitsel araç ve gereçlerin yararlı olduğuna ikna etmek gerekir. En iyi özelliklerle donatılmış materyaller, öğretmenin elinde değer kazanır.

\subsection{Türkçe öğretiminde materyal kullanımı}

İçeriği daha anlaşılır hâle getiren ve zamandan tasarruf sağlayan materyaller, Türkçenin yabancı dil / ikinci dil olarak öğretiminde de etkili bir öğrenme sürecinin olmazsa olmazı durumundadır (Duman, 2013). Türkçe öğretiminin yurt içinde ve yurt dışında yaygınlaşmasıyla, geliştirilen materyallerin sayısı ve niteliği artmaktadır. Bu gelişim, öğretimin daha etkili ve verimli olmasını sağladı̆̆ gibi Türkçeyi öğrenenlere zengin materyaller de sunmaktadır (Biçer, 2016). Bu gelişmelere rağmen hâlâ Türkçe öğretimiyle ilgili alınacak önemli mesafeler vardır. Sülükçü (2011) Türkçenin yabancı dil olarak öğretimi alanında farklı gruplar göz önünde bulundurularak materyallerin hazırlanması gerektiğini ifade eder. Hazırlanan materyallerin niteliği ve çeşitliliğindeki artış, eğitim sürecinin kalitesinde yükselmeyi de beraberinde getirecektir.

Türkçenin yabancı / ikinci dil olarak öğretiminde görsel, işitsel, çok duyulu araçlardan, kültürel obje ve materyallerden yararlanılmalıdır (Şengül, 2015). Fuller (2001) yabancı bir dil öğrenilirken hedef dille ilgili nitelikli malzemelerin, farklı kaynakların ve işitsel ögelerin kullanımının öğrenme sürecine önemli katkılar sağladığını belirtir. Yılmaz ve Talas’a (2015) göre öğrenme ortamının düzenlenmesi ve öğrencilerin dikkatini çekebilmek için geliştirilen materyallerin dikkatli ve amaca hizmet edecek şekilde seçilmesi gerekir. Dikkatle seçilecek öğrenme materyalleri öğrenmenin niteliğini de belirler. Yabancı dil öğretiminde kullanılan materyaller sınıf içerisinde doğal bir dil ortamını mümkün kılmakta ve bu şekildeki gerçek ortamlara yakın bir sistem içerisinde yabancı bir dili öğrenimi de öğrencinin ilgisini çekmektedir (Demirel, 1990). Fries'e (1959) göre dil öğretiminde kullanılacak materyaller, öğrenenlerde farklı bir kavrayış deneyimini aşamalı olarak geliştirmelidir. Dil materyalleri öğrencilerin yabancı dildeki soyut ve karmaşık görünen kavram ve ifadeleri zihinde yapılandırmaya önemli oranda yardım eder.

Yabancılara Türkçe öğretmek için hazırlanan çok çeşitli materyaller arasından ders ve çalışma kitapları sınıf içerisinde en fazla kullanılan materyallerdir. Oysa materyal sayısı ve çeşidinin artması tekrar sayısını artırırken öğrenmeyi kalıcı hâle getirecek; doğal olarak Türkçe öğrenen bir yabancı, öğretmenin sınıfta verdiği bir kelimeyle yazılı bir materyalde, dinlediği bir şarkıda karşılaşır, hatta o sözcüğü cümlede kullanırsa unutması daha zor olacaktır (Duman, 2013: 5) Doğal dil ortamı oluşturmada önemli rolü olan bu materyaller dil öğrenmeyi de yapaylıktan çıkararak gerçek yaşamla bağlantıyı kurarlar.

Dil öğretiminde materyallerin öğrenme sürecine katkısında öğretmenlere önemli sorumluluklar düşmektedir. Öğretmenlerin dil öğretim sürecini etkili bir şekilde yürütebilmelerinde, dilin doğasını, kültürlerarası ilişkileri, öğrenme alanını ve bilimsel gelişmeleri dikkate almaları gerekmektedir (Şengül, 2015). Öğretmen ders içeriklerine uygun, hedef dili doğal kültürel ortamındaki gibi edindirecek gerçek yaşam temelli materyalleri seçebilmeli ve bu tür materyaller geliştirebilme becerilerine sahip olmalıdır (Akpınar Dellal ve Seyhan Yücel, 2015). Materyal geliştirmeyle var olan materyalleri uyarlayarak veya yenilerini üreterek öğretilmesi, hedeflenen yabancı dilin öğrenim sürecini kolaylaştırırlar (Tarakcığlu, 2012: 5). Böylece yapılacak etkinliklerle, kullanılacak materyallerle öğrencinin eğlenerek öğrenmesi sağlanacaktır (Şen, 2015). Öğrencinin eğlenerek öğrenmesi hedef dile karşı ilgi ve motivasyonunu da artıracaktır. Dil öğretiminin önemli ilkelerinden olan motivasyonu sağlama ilkesi (Barın, 2004) eğitim ortamlarında uygun materyallerle sağlanabilir. 
Eğitim ve öğretim ortamlarında materyal kullanımın durumunu inceleyen çok sayıda araştırma bulunmaktadır. Bu çalışmalar arasında Karamustafaoğlu (2006), Kurtdede Fidan (2008), Şad ve Arıbaş (2008), Karamustafaoğlu ve diğerleri (2012), Özer ve Tunca (2014), Korkmaz’n (2018) yaptığı araştırmalar bulunmaktadır. Türkçenin yabancı dil olarak öğretimiyle ilgili yapılan çalışmalara bakıldığında ise Haciömeroğlu (2007), Sülükçü (2011), Artuç (2013), Duman (2013), Ilgar (2013), Özdemir (2013), Doğan (2014), Kanğ (2015), Şengül (2015), Yılmaz ve Talas (2015), Altıparmak ve Özcan (2016) ve Taşköprü (2017) gibi çalışmalar tespit edilmiştir.

Yabancı dil olarak Türkçe öğrenme ortamlarından Suriyeli göçmen öğrencilerin olduğu sınıflarda materyallerin etkisinin daha fazla hissedildiğini söylemek mümkündür. Kısıtlı imkânlarla dil entegrasyonunun sağlanmaya çalışıldığı bu öğrencilere Türkçe öğreten kişilere daha fazla sorumluluk düşmektedir. Bu çalışma Suriyeli öğrencilerin eğitim ortamlarındaki materyal kullanım durumlarının belirlenmesine katkı sağlayacaktır.

\section{2. Çalışmanın amacı}

Bu çalışmada Suriyeli öğrencilere Türkçe öğretimi alanında görevli öğretmenlerin materyal hazırlama, geliştirme ve kullanma durumlarına ilişkin görüşlerinin belirlenmesi amaçlanmıştır. Bu genel amaç doğrultusunda öğrencilerin hazır bulunuşluk düzeylerine, temel öğretim ilkelerine, dört temel dil becerisini geliştirebilmesine, öğrenci merkezli yaklaşımlara, ölçme ve değerlendirme amaçlı kullanılabilmesine, kültürel kodlarımızı aktarabilmesine, zor öğrencileri öğretim sürecine dâhil edebilmesine, materyal hazırlama ilkelerine, çoklu öğrenme ortamı sağlayabilmesine ilişkin katılımcı görüşlerinin belirlenmesi hedeflenmiştir.

\section{Yöntem}

\section{1. Çalışmanın deseni}

Çalışmada farkında olunan ancak tam olarak bilinmeyen bir olgunun tanımlanmasını amaçlandığından nitel türde olgubilimsel (fenomenolojik) desen tercih edilmiş; ilgili olguya yönelik deneyimlerin, ortak anlamların somutlaştırılması amaçlanmıştır (Creswell, 2016a; 2016b). Bu türden çalışmalarda katılımcıların olguya ilişkin gerçek düşüncelerinin tespit edilmesi son derece önemlidir ve bu nedenle de güven ve empatiye dayalı görüşme tekniği veri toplamada tercih edilmiştir (Büyüköztürk vd., 2014). Bu ve benzeri çalışmalarda olgunun kendi ortamında akılcı, gerçekçi, bütüncül bir şekilde aydınlatılması esastır (Patton, 2014; Yıldırım ve Şimşek, 2005). Bu türden çalışmalarda bir kesit üzerinden uzun süreli ve yoğun bir etkileşim içerisinde bulunulmalı, çalışma yapılan ortamın özelliklerine bütüncül bir şekilde bakılmalıdır (Miles ve Huberman, 2016).

\section{2. Çalışma grubu}

Çalışma grubu; Türkiye'de Suriyeli göçmenler için kurulmuş konaklama merkezlerinde, geçici eğitim merkezlerinde ve Türkiye'deki devlet okullarında Suriyeli öğrencilere Türkçe öğretmeleri için görevlendirilen öğretmenlerden oluşmaktadır. 2016-2017 eğitim-öğretim yılında Kilis ilinde görev yapan öğretmenlerden, nitel çalışmaların doğasına daha uygun olan amaçlı örnekleme yöntemiyle (Miles ve Huberman, 2016) seçilen 6 erkek, 5 kadın toplam 11 öğretmen çalışma grubunu oluşturmaktadır. Çalışma gurubu tespit etme süreci, nitel çalışmalara uygun şekilde yeterli veri toplandı̆̆ düşünüldüğü ve sürekli benzer veriler gelmeye başlandığı 11. katılımcı ile tamamlanmıştır. $\mathrm{Bu}$ türden çalışmalarda; örneklem büyüklüğünden çok, elde edilen verilerin araştırmacıların, 
çalışmanın ihtiyacını karşılayıp karşılamaması dikkate alınır (Türnüklü, 200o). Araştırmacılar görüşmelerde gerçek görüşlerin elde edilebilmesi için katılımcıları gerçek adları ile raporlamamış; K1, K2... şeklinde kodlamıştır. Katılımcılara ilişkin bilgiler Tablo 1'de gösterilmiştir:

Tablo 1. Katılımcllara ait bilgiler

\begin{tabular}{lll}
\hline \multirow{2}{*}{ Cinsiyet } & Kadın & 5 \\
& Erkek & 6 \\
\hline \multirow{2}{*}{ Eğitim durumu } & Lisans & 7 \\
& Yüksek lisans & 4 \\
\hline
\end{tabular}

\subsection{Veri toplama aracının geliștirilmesi}

Çalışma kapsamında 8 maddelik görüşme formu, veri toplama aracı olarak kullanılmıştır. Bire bir görüşme tekniğinin kullanıldığı çalışmada olguya yönelik bilgi, görüş, tutum ve davranışların bütüncül olarak belirlenmesine, tanımlanmasına çalışılmıştır (Karasar, 2009). Olgubilimsel desendeki nitel çalışmaların doğasına uygun olarak katılımcıların bağımsız düşünebilmesi hedeflenmiş ve bu nedenle de veri toplama sürecinde yarı yapılandırılmış, açı uçlu sorular tercih edilip gerekli durumlarda ek sorular yöneltilmesi mümkün kılınmıştır. Görüşme formundaki maddelerin her birinin araştırma olgusunun farklı bir yönünü aydınlatması amaçlanmıştır. Görüşme formu hazırlanırken ilk olarak alan yazın taranmış ve ölçütler belirlenmiştir. Bu doğrultuda hazırlanan belirtke tablosuna uygun olarak taslak ölçek maddeleri yazılmıştır. Kapsam geçerliliği için Fırat, Kafkas ve Kilis 7 Aralık üniversiteleri eğitim fakültelerinde Türkçe eğitimi ana bilim dallarında görevli 4 öğretim üyesinden ilgili görüşme formunu değerlendirmeleri istenmiştir. Yine Kilis ilinde Suriyelilere Türkçe öğretmek amacıyla görevlendirilmiş ve aktif olarak görev yapan 5 öğretmeninin görüşleri alınmıştır. İlgili kişilerden gelen görüş ve değerlendirmelerden hareketle görüşme formundaki maddeler tekrar kontrol edilmiş, birtakım düzeltmeler ve eklemeler yapılmıştır. Bu yolla görüşme formu bire bir görüşmelere hazır hâle getirilmiştir.

\subsection{Verilerin analizi}

Araştırmacılar tarafından veri toplamak amacıyla katılımcılarla bire bir görüşmeler gerçekleştirilmiş, ses kayıt cihazıyla kayıt altına alınan tüm veriler bilgisayar ortamında çözümlenerek yazılı hâle getirilmiştir. Çalışmada verilerin analizinde içerik ve betimsel analiz teknikleri birlikte kullanılmıştır. Çalışmanın "inandırıcılığının" sağlanması için araştırmacılar tarafından yazılı hâle getirilen metinler, katılımcılara kontrol ettirilerek katılımcı teyidi alınmıştır. "Aktarılabilirliğin" sağlanması için görüşme öncesinde katılımcılara araştırma süreciyle ilgili ayrıntılı bilgi verilmiştir. Bu türden nitel çalışmalarda kodlama; metni küçük parçalara bölme, tespit edilen her birimi etiketleme, temaların katılımcılar ve araştırmacıların ifade tercihleri ve ilgili alan yazından hareketle sınıflandırılması amaçlanır (Creswell ve Plano Clark, 2015). Veriler çözümlenip değerlendirilirken benzer cevaplar kategorize edilmiş, cevapların toplam oran içerisindeki frekansları verilmiş ve maddelere verilen cevapların yer aldığı tablolar yorumlanmıştır. Nitel türde araştırmalardaki aksiyolojik öznelliğin, keyfi bir öznelliğe dönüşmemesi için kodlayıcı güvenirliği son derece önemlidir. Bu nedenle çalışmayı yürüten iki araştırmacının birbirlerinden bağımsız yaptıkları kodlama eylemi sonucunda görüş birliği sağlanan kodların, görüş birliği sağlanan ve görüş birliği sağlanmayan kodların toplamına bölünüp 100 ile çarpılması sonucu tespit edilen \%74'lük uyum yüzdesinden hareketle "kodlayıcı güvenirliğinin" yeterli olduğu kanaatine ulaşılmıştır (Miles ve Huberman, 2016). Son olarak da "kategori netliğinin" 
sağlanabilmesi için araştırmacılar tarafından yapılan sınıflandırmanın alan yazın ile uyumlu, açık ve net olmasına özen gösterilmiştir (Bilgin, 2014; Sönmez ve Alacapınar, 2016).

\section{Bulgular ve yorumlar}

Bu bölümde bulgular, alt amaçlar doğrultusunda çözümlenmiş ve belirlenen kodlar sinıflandırılıp yorumlanmıştır. Tablo 2'de öğrenme materyallerinin öğrencilerin hazır bulunuşluk düzeyleri açısından değerlendirilmesine ilişkin katılımcı görüşleri verilmiştir:

Tablo 2. Öğrencilerin hazırbulunuşluk düzeyleri açısından ders araç-gereçleri ve materyallere yönelik katılımcı görüşleri

\begin{tabular}{cccc}
\hline Hazırbulunuşluk düzeyi & Olumlu & $\begin{array}{c}\text { f } \\
\text { Olumsuz }\end{array}$ & Toplam \\
\hline Bilgi düzeyi & 2 & 12 & 14 \\
Sosyokültürel yapı & 2 & 11 & 13 \\
Bireysel farklar & 2 & 10 & 12 \\
Illgi ve ihtiyaçlar & 1 & 7 & 8 \\
Öğrenme hızı & 2 & 5 & 7 \\
Motivasyon & - & 5 & 5 \\
Okur-yazarlık düzeyi & 1 & 3 & 4 \\
Sinıf düzeyi & 1 & 3 & 4 \\
Tutum & 1 & 2 & 3 \\
Konuşma becerisi & - & 2 & 2 \\
Disiplin & - & 2 & 2 \\
Kaynak-hedef dil ilişkisi & - & 1 & 1 \\
Çoklu öğrenme & - & 1 & 1 \\
Dikkat & - & $\mathbf{6 5}$ & 77 \\
Toplam & $\mathbf{1 2}$ & & \\
\hline
\end{tabular}

Katılımcılar; öğrencilerin hazır bulunuşluk düzeylerine göre ders araç-gereci ve materyal hazırlayıp kullanabilmelerine ilişkin olarak materyallerde görselleri etkili kullanamadıklarına, öğrencilerin hazır bulunuşluk düzeylerinin oldukça düşük olduğuna, birçok üst sınıfta öğrencilerin hâlâ alfabe ve okuryazarlık noktasında ciddi problemleri olduğuna dikkat çekmiştir. Öğrencilerin sağ taraftan yazmaya alışık olduklarından, yazma dil becerisinin geliştirilmesinde sorun yaşadıklarını ifade etmişlerdir. Öğrencilerin aile ve çevrelerindeki problemleri öğrenme ortamına aktardıklarına, davranış problemi olan çok fazla öğrenci bulunduğuna, öğrenme hızlarının Türk öğrencilere göre oldukça düşük olduğuna dikkat çekilmiştir. Bu ve benzeri nedenlerle öğrencilerin Türkçeye karşı olumsuz tutum geliştirebildikleri ve materyallerden yeterince yararlanamadıkları dile getirilmiştir. Bunda farklı yaş grubundaki öğrencilerin aynı sınıflarda eğitim almasının etkili olduğu düşünülmektedir. Materyal geliştirme noktasında çoklu öğrenmeyi mümkün kılacak şekilde birden fazla duyu organını öğrenme ortamında aktif duruma getirecek araç-gereci ve materyali geliştirmede sıkıntı yaşadıkları belirtilmiştir. Ayrıca öğrencilerin resim, müzik gibi sanat dallarına ilgileri nedeniyle görsel destekli ders araç-gereçleri ve materyallerin geliştirilmesinin ve tercih edilmesinin, bu türden bireysel 
farklılıkların giderilmesinde yararlı olacağı söylenmiştir. Katılımcılardan K4 ve K7’nin bu husustaki görüşleri şöyledir:

K-4: Ders araç ve gereçleri öğrenci seviyelerine uygun olmalı. İlkokul 2 ve 3. sinıf öğrencilerine okuma ve yazma etkinliklerine fazla yer verilmeli, alfabe öğretimini, alfabe treni vb. materyallerle zenginleştirilmeli. Öğrencilerin defter kitap kullanımına yönelik etkinlikler yapılmalı, Arapçada olduğu gibi sağ taraftan defter, kullanımına başlanmamalı. Materyaller öğrencilerin birden çok duyu organına hitap etmeli. Kitaplar öğrencilerin ilgisini çekebilecek formatta düzenlenmemiş. İlkokul için elimizdeki kitapların uygun olduğunu düşünmüyorum. Öğrenciler bulundukları coğrafya bakımından da kültürümüze çok yabancı değiller. Buradan hareketle bilgi aktarımları, kültürel aktarımlar çok fazla zor olmuyor. Bilgi düzeyleri elbette yeterli değil, ancak öğrenme hızları normal seviyede. Türkçe öğretiminde kullanılan materyaller hedef kitlenin ilgi ve ihtiyaçlarına uygun olmalıdır. Öncelikle öğrencilerin hazır bulunuşluk durumlarının aynı olmadığını düşünüyorum.

K-7: Sınıfımda öğrenme hızı, hazır bulunuşluk seviyesi, yaş, ait oldukları sosyokültürel kodlar bakımından farklı öğrenciler bulunmaktadır. Öğrencilerimde elimden geldiği kadar bu farklılığa hitap etmeye gayret ediyorum. Sinıfta diğer bilen öğrencilere materyal basit geldiği için öğrenciler sıkılmakta ve disiplin sorunları ortaya çıkmaktadır. Sınıflar seviye gruplarına ayrılıp hedef kitleye yönelik materyaller hazırlanmalıdır. Şu an sınıfta her dil seviyesinden öğrenciler olduğu için hazırlanan materyal ya çok kolay olmakta ya da çok zor olmakta. Öğrencilerin hazır bulunuşluk düzeyleri arasında çok fark olması eğitim-öğretim uygulamalarında sorun yaratmakta. Bu farklar genelde öğrenme hızlarıyla bilgi düzeyleri arasında olmaktadır. İstekli olmakla beraber bilgi düzeyleri yüksek olanlar daha hızlı bir şekilde öğrenme gerçekleştirmektedir.

Tablo 3. Temel öğretim ilkeleri açısından ders araç-gereçleri ve materyallere yönelik katılımcı görüşleri

\begin{tabular}{|c|c|c|c|}
\hline \multirow{2}{*}{ Temel öğretim ilkeleri } & \multicolumn{3}{|c|}{$\mathbf{f}$} \\
\hline & Olumlu & Olumsuz & Toplam \\
\hline Genel öğretim ilkeleri & 4 & 3 & 7 \\
\hline Basitten zora ilkesi & 4 & 1 & 5 \\
\hline Bilgiyi somutlaştırma & 4 & - & 4 \\
\hline Gündelik dil kullanımı & 1 & 1 & 2 \\
\hline Hayatîlik ilkesi & 2 & - & 2 \\
\hline Bireysel çaba & 2 & - & 2 \\
\hline İçerik & - & 1 & 1 \\
\hline Çoklu öğrenme & 1 & - & 1 \\
\hline Bilginin kalıcılığı & 1 & - & 1 \\
\hline Sarmal eğitim & - & 1 & 1 \\
\hline Bireysel farklar & - & 1 & 1 \\
\hline Somuttan soyuta ilkesi & - & 1 & 1 \\
\hline Yakından uzağa ilkesi & - & 1 & 1 \\
\hline Toplam & 19 & 10 & 29 \\
\hline
\end{tabular}

Katılımcılar, temel öğretim ilkelerini gözeten yeterli sayıda materyale sahip olmadıklarını, ders araçgereçleri ile materyallerin öğrencilerin hedef dildeki iletişimsel yeti düzeylerini geliştirmediğini, bu yönde rehberliğe ihtiyaç duyduklarını dile getirmişlerdir. Kalabalık sınıflar, öğretim sürecindeki en önemli sorunlardan biri olarak gösterilmiş ve çözüm önerisi olarak da başta projeksiyon olmak üzere teknolojik kaynaklı araçların kullanımı gösterilmiştir. Bu yolla özellikle bilginin somutlaştırılmasında olumlu sonuçlar aldıklarını dile getirmişlerdir. Öğrencilerin hedef dildeki iletişimsel yetilerini artırmak için çoklu öğrenmeyi mümkün kılacak araç-gereçler ile materyallerin kullanılmasının, ders kitaplarındaki içeriğin basitten karmaşığa ilkesine ve kültürleme edimine uygun şekilde 
düzenlenmesinin, farklı kültürel ve sosyal alanlarda zenginleştirilmiş metinlere/içeriğe yer verilmesinin yararlı olacağı dile getirilmiştir. Yine iletişimsel yetinin geliştirilmesinde hayatîlik ilkesinden hareketle gündelik hayatta daha yoğun kullandıkları konuşma ve dinleme becerilerine yönelik ders-araç-gereçleri hazırlamaya çalıştıklarını dile getirmişlerdir. Ayrıca çeşitli kaynaklardan temin ettikleri ders araç-gereçleri ile materyalleri özellikle görsellik açısından yeniden düzenleyerek sarmal eğitim noktasındaki eksikleri aşmaya çalıştıklarını belirtmişlerdir. Derslerin zevkli hâle getirilmesi adına uygulama ve öğrenci merkezli dersleri mümkün kılan materyalleri öncelediklerini söylemişlerdir. Bu görüşlere ilişkin K5 ve K6 düşüncelerini şu sözlerle dile getirmişlerdir:

K-5: Veli eğitimine önem verip, öğrencilere (6-12 yaş) basitleştirerek; öğretim ilkelerine kendim uyarlamaya çalışıyorum. Çocukların hem yaşlarının küçük olması hem de dünyayı algılama biçimleri bizden daha farklı olduğu için özellikle somutlaştırma, görselleştirme yöntemini çok kullanıyorum. Öğrencilerimin yaş seviyesi küçük olduğu için araç gereçleri ve materyalleri daha çok somutlaştırarak kullanıyorum. Araç gereç olarak verilen kitapların eksik yönü her yaş grubuna aynı kitabın verilmesi. Sarmal eğitim kullanılması uygun görüyorum.

K-6: Benim öğrencilerimin sayısı 45-50 civarı olduğundan araç kullanımında sıkıntı yaşıyorum ve sınıfımın seviyesi oldukça zayıf. Bundan dolayı daha çok ilk zamanlar okuma yazma etkinlikleri uyguladım. Sınıf çok değişken olduğundan kendi görsellerimizi çizip fotokopi olarak uyguluyoruz. Kullandığımız ders kitabımız seviyelerine uygun değil. Aynı kitap her kademeye verildiği için öğrencinin bilgilerine hitap etmiyor. Hazır materyal kullanmayıp ben hazırlarken temel öğretim ilkelerine dikkat ediyorum. Ama genelde öğrencilerin düzeyi kötü. Fakat yansitma aracı ile yaptığımız çalışmalar bu ilkelerin hemen hepsine hitap edebiliyor. Alfabe öğretimi, heceler, kelimeler ve cümleler şeklinde izlediğimiz sırada sesli, görüntülü veriler hem basit ve kolay hem de somuttur.

Tablo 4. Temel iletişim becerileri açısından ders araç-gereçleri ve materyallere yönelik katılımcı görüşleri

\begin{tabular}{|c|c|c|c|}
\hline \multirow{2}{*}{ Temel iletişim becerileri } & \multicolumn{3}{|c|}{$\mathbf{f}$} \\
\hline & Olumlu & Olumsuz & Toplam \\
\hline Dört temel dil becerisi & 4 & 7 & 11 \\
\hline Teknoloji kullanımı & 3 & 5 & 8 \\
\hline Doğal dil becerileri & 1 & 3 & 4 \\
\hline Dinleme & - & 4 & 4 \\
\hline Çoklu öğrenme & - & 2 & 2 \\
\hline Okuma & - & 2 & 2 \\
\hline Konuşma & 1 & 1 & 2 \\
\hline İletişimsel yeti & - & 1 & 1 \\
\hline Anlama becerileri & - & 1 & 1 \\
\hline Yazma & - & 1 & 1 \\
\hline Drama & - & 1 & 1 \\
\hline Okur-yazarlık & - & 1 & 1 \\
\hline Toplam & 9 & 29 & 38 \\
\hline
\end{tabular}

Katılımcılar; konuşma ve dinleme becerilerini gözlemleyebilecekleri yeterli etkinlik olmamasından, doğal olarak da dört temel dil becerisini geliştirme noktasında yetersiz kaldıklarından yakınmışlardır. Sınıfların teknolojik olarak donatılmamasının dinleme becerisinin geliştirilmesinde aksaklıklara yol açtığından yakınılmıştır. Özellikle dinleme becerisine yönelik etkinlik, uygulama ve yönergelere zaman sıkıntısından dolayı etkili bir şekilde yer vermediklerinden, öğretmene çok fazla iş düştüğünden şikayet edilmiş; öğretmen kalitesinin belirleyici olduğu dile getirilmiştir. Yine geliştirilen veya seçilen 
materyal, ders araç-gereçlerinin çoklu öğrenmeyi mümkün kılacak yapıda olmadığı, daha çok ders kitaplarıyla sınırlı kalındığı; özellikle çağdaş ölçme ve değerlendirme uygulamalarına yer verilmediği, doğal dil becerilerinin bu yönden ihmal edildiği dile getirilmiştir. Kullanılan materyal ve ders araçgereçlerinin ne bütüncül ne de analitik türden bir ölçme değerlendirme yaklaşımına uygun olmadığı, üstelik programın da bunun için uygun olmadığı söylenmiştir. Öğrencilerin okuma ve yazma bilmemeleri ya da okur-yazarlık düzeylerinin son derece düşük olması, hatta alfabeyi tam olarak çözememeleri dikkat çekilen diğer önemli sorunlardır. Katılımcıların teknoloji destekli materyal kullanımının dört temel dil becerisinin bütüncül olarak geliştirilmesinde katkısı olduğu, öğrencilerin ilgilerini çektiği yönündeki görüşleri dikkat çeken olumlu tespitlerdir. Gündelik yaşamlarında iletişimsel ihtiyaçlarını giderecek uygulama ve yaklaşımlara yer vermeye çalıştıklarını, ancak bunda çok fazla başarılı olamadıklarını söylemişlerdir. Bu konuda K9 ve K11’in görüşleri şu şekildedir:

K-9: Materyaller görünüşte daha çok okuma, yazma ve konuşma ağırlıklı olarak tasarlanmaktadır. Anne karnindan başlayan ve edinilen ilk dil becerisi dinleme ise bir nebze geri planda bırakılmaktadır. Birbirinden bağımsız birer dil alanı (becerisi) olarak düşünülmesi imkânsız olan bu becerilerin eş güdümlü olarak ilerletilmesi gerekmektedir. Kullandığım materyaller dört temel iletişim becerisini geliștiriyor. Kitap kullanıyorum okuma becerisi gelișiyor. Defter kullandırtıyorum yazma becerisi gelişiyor. Öğrendiklerinizi anlatın diyorum konuşma becerisi gelişiyor. Ben ders anlatıyorum, sürekli muhabbet ediyorum dinleme becerisi gelişiyor. Araç gereç olarak sınıfta bulunan; sıra, masa, tahta başka da bir şey bulunmamakta.

K-11: Dil öğretimi bir bütündür. Kullanılan materyaller dört temel beceriye de hitap etmeli ve bu becerileri geliştirmelidir. Okuma ve yazmada etkin olan materyal, konuşma ve dinleme etkinliklerine kısıtlı yer verilmiştir. Özellikle drama çalışmalarının olmaması sıkıntılıdır. Öğrencilerim okuma yazma bilmediği için ders materyalleri ve araç gereçleri ihtiyacımızı karşlamıyor. Alfabe öğretimi bitince kitaptaki etkinliklere başladık. Bütün kademeler için aynı kitabın kullanılması, ilkokul kademesi için uygun değil. Materyalin olması becerilerin çok daha fazla gelişmesini sağlar. Maalesef ki elimizde teknolojik herhangi bir materyal bulunmuyor.

Tablo 5. Öğretmen veya öğrenci merkezlilik açısından ders araç-gereçleri ve materyallere yönelik katılımcı görüşleri

\section{Öğretmen veya öğrenci merkezlilik}

\section{f}

$\begin{array}{cccc}\text { Öğretmen faktörü } & 7 & 5 & 12 \\ \text { Öğrenci merkezlilik } & 4 & 7 & 11 \\ \text { Yaparak öğrenme } & 2 & 3 & 5 \\ \text { Öğretmen merkezlilik } & - & 3 & 3 \\ \text { Oyun merkezli öğretim } & 2 & 1 & 3 \\ \text { Disiplin } & - & 3 & 3 \\ \text { Ders süreleri } & - & 2 & 2 \\ \text { Sinıf mevcudu } & - & 2 & 2 \\ \text { Bütüncül yaklaşım } & 1 & - & 1 \\ \text { Çok boyutluluk } & 1 & - & 1 \\ \text { Teknoloji kullanımı } & - & 1 & 1 \\ \text { Gözlem } & 1 & - & 1 \\ \text { Yeni bilgi sunma } & 1 & - & 1 \\ \text { Eğitim alıskanlıkları } & - & 1 & 1 \\ \text { Sinıf yönetimi } & - & 1 & 1\end{array}$




\begin{tabular}{cccc}
\hline Öğretmen veya öğrenci merkezlilik & f & \\
& Olumlu & Olumsuz & Toplam \\
\hline Etkinlik & - & 1 & 1 \\
Toplam & 19 & 30 & 49 \\
\hline
\end{tabular}

Katılımcllar; öğrencinin aktif hâle getirilmesinde öğretmen faktörünün çok belirleyici olduğuna, öğretmenin hazır materyaller kullanmak yerine kendi hazırladıklarını tercih etmesi gerektiğine dikkat çekmiştir. Bu noktada sınıfların aşırı kalabalık olmasının engel teşkil ettiğinden, yol göstericilik açısından etkili materyal bulamadıklarından ve uygulama merkezli ders araç-gereçleri ile materyal temininde zorlandıklarından, bu nedenle öğretmen merkezli derslerin ağırlıklı olduğundan yakınılmıştır. Ayrıca etkili ders araç-gereci ve materyal hazırlama, temin etme ile ilgili eğitim almaları gerektiğine dair görüşler de ön plana çıkmaktadır. Yine bir diğer katılımcı, öğrencilerin davranış ve disiplin problemleri bulunduğunu ve uygulama merkezli araç-gereçlerin/materyallerin bu soruna çözüm olduğunu dile getirmiştir. Bazı katılımcılar $(n=2)$, öğretmen merkezli yaklaşım ve uygulamaların daha etkili olduğunu, öğrenci merkezli yaklaşımların eğitsel ortamlarda davranış ve disiplin problemlerine yol açtığını belirtmiştir. Bununla birlikte çözüm önerisi olarak öğretmen kalitesinin yükseltilmesi, zengin ve amaca yönelik materyal kullanımı, yaşantı merkezli öğrenme ortamları, birden fazla duyu organını harekete geçiren çoklu öğrenmeye dayalı ders araç-gereçlerinin tercih edilmesi dile getirilmiştir. Öğretmenin öğrenme rehberi pozisyonunu koruması; merkeze öğrenciyi, hedefe de öğrenmeyi alması gerektiği belirtilmiştir. Öğrencilerin davranış ve disiplin problemlerinin giderilebilmesi için uygulama merkezli materyaller ile etkin sinıf yönetimi becerisi ve öğretmenin eğitim liderliği rolünün ön plana çımasının faydalı olacağı yönündeki görüşler tespit edilmiştir. Bu hususta görüşlerini dile getiren K1 ve K7’nin düşünceleri şöyledir:

K-1: Öğrenciyi aktif hale getirecek olan biz eğiticileriz, bunu sağlamamız için bize yönelik hazırlanmış bir kaynak yok. Sınıflarımız çok kalabalık olduğundan konuşma ve dinleme becerileri başta olmak üzere her öğrenciye yeterince vakit ayıramıyoruz. Bu durum derslerde öğrencilerin aktif olmasını engellemektedir. Uygulamalara yer verilse bile sinıfın bu fiziki durumu bunu engellemektedir. Sinıfların ideal öğrenci sayısında olması durumunda öğrenciler daha aktif olacaktır.

K-7: Uygulamada öncelikle öğrenciyi hedef almaktayım, ben de materyallerde öğrenciyi destekleyecek şekilde yardımcı oluyorum. Öğrenciler biraz yaramaz olduğu için onları hiçbir zaman boş bırakmamak adına derse girmeden önce öğrenciyi aktif hale getirecek materyaller hazırlıyorum. Uygulamada öğretmen rehber olmalı, sinıfta daima müdahale edecek, arada dönüp düzeltme yapacak şekilde dolaşmalıdır. Öğrenci aktif, öğretmen rehber olmalıdır. Tasarlanan materyaller öğrenci merkezli hazırlanırsa öğrenci için daha faydalı olacaktır. Ama ne kadar da öğrenci işin içinde olsa öğretmenin etkisi her zaman ön planda olmaktadır.

Tablo 6. Ölçme ve değerlendirme açısından ders araç-gereçleri ve materyallere yönelik katılımcı görüşleri

\begin{tabular}{|c|c|c|c|}
\hline \multirow{2}{*}{ Ölçme ve değerlendirme } & \multicolumn{3}{|c|}{$\mathbf{f}$} \\
\hline & Olumlu & Olumsuz & Toplam \\
\hline Geleneksel ölçme ve değerlendirme & 2 & 5 & 7 \\
\hline Öğretmen faktörü & 3 & 1 & 4 \\
\hline Kazanımlar & - & 4 & 4 \\
\hline Teknoloji kullanımı & 1 & 1 & 2 \\
\hline Beceri merkezli eğitim & 2 & - & 2 \\
\hline Ana dili eğitimindeki ölçmeden aktarım & - & 1 & 1 \\
\hline
\end{tabular}




\begin{tabular}{cccc}
\hline Ölçme ve değerlendirme & f & \\
& Olumlu & Olumsuz & Toplam \\
\hline Dönüt & 1 & - & 1 \\
Gözlem & 1 & - & 1 \\
Analitik ölçme ve değerlendirme & 1 & - & 1 \\
Kapsam geçerliği & - & 1 & 1 \\
Toplam & $\mathbf{1 1}$ & $\mathbf{1 3}$ & $\mathbf{2 4}$ \\
\hline
\end{tabular}

Katılımcılar; öğrenci seviyesini gözeten standart ölçme ve değerlendirme testlerinin bulunmadığından yakınmış, bu durumun da bütüncül (holistic) ve analitik ölçme-değerlendirme uygulamalarını zorlaştırdığından beceri merkezli ölçme ve değerlendirme yapmayı bilmediklerinden ve bu noktadaki belirsizlikten yakınmışlardır. Aynı katılımcı (K-2), ölçme ve değerlendirmede teknolojiyi aktif olarak kullanamadıklarını da söylemiştir. Ders araç-gereçlerinin -başta ders kitapları olmak üzere- ölçme ve değerlendirme açısından yetersiz olduğu ifade edilmiş, öğretmen kalite ve yeterliğinin bu açıdan önemli olduğu; farklı sınıf düzeylerinde aynı kaynakların, ders araç-gereçlerinin, materyallerinin kullanılmasının sınıf genelinde bütün öğrencileri gözlemlemeyi zorlaştırdı̆̆ı belirtilmiştir. Öğrenci seviyelerinin ve sınıf düzeylerinin ölçme ve değerlendirme açısından gözetilmediği ifade edilmiştir. Ölçme ve değerlendirme açısından etkinlikleri yetersiz bulan bir diğer katılımcı; ürün odakl, geleneksel ölçme ve değerlendirmelere yöneldiğini, Türkçenin ana dili olarak eğitiminden uygulama düzeyinde aktarmalar yaptığını; mevcut durumun tek tip, geleneksel ölçme ve değerlendirme uygulama ve alışkanlıklarına yönelttiğini dile getirmiştir. Gözlem yaparak öğrencinin performansının değerlendirilemeyeceğini, geleneksel yöntemlerin -başta yazılı sınavlar- kullanılması gerektiği de ifade edilmiştir. Dinleme becerilerinin ölçülmesinde son derece yetersiz olduklarını dile getirmişlerdir. Katılımcılar, alıştırmalarda ve etkinliklerde anında dönüt verebilme imkânına sahip olduklarını; sınav kâğıtlarını hazırlarken hazır soru kullanmak yerine kendi hazırladıkları yazılı sınavlarla öğrenci seviyelerini daha rahat tespit edebildiklerini söylemişlerdir. Ders araç ve gereçleri ile materyallerinin ölçme ve değerlendirme için kullanılması çoklu öğrenmeyi mümkün kıldığı; ayrıca bu yolla konuşma becerilerinin daha rahat gözlemlenebileceği de dile getirilmiştir. Bu hususa ilişkin K1 ile K8'in görüşleri şöyledir:

K-1: Öğrenci seviyesine göre hazırlanmış standart ölçme ve değerlendirme testleri yok. Genel olarak yabancı dil öğretimi ile ilgili alanı taradığımızda da her üniversite farklı bir yayın kullandığından bir birliktelik yok. Soru nasıl hazırlamalıyız, hangi beceriler için hangi ölçütler kullanmalıyız, bu noktalarda büyük karmaşa var. Öğrenci seviyeleri aynı sınıf içinde farklı olduğu için kazanımlar ve ölçme değerlendirme bu duruma uygun hazırlanmamıştır. Öğrenci aktif hale getirilmeye çalışılıyor, ama sınıfların kalabalık olması yüzünden her öğrenciyi derse katamıyoruz.

K-8: Kullanılan araç-gereçler ölçme ve değerlendirmeye uygun bir şekilde tasarlanmışsa, eğer kazanımların kazandırılmasına da uygunsa kullanılabilir. Kullanılan araç-gereçlerin kazanımlara uygun olduğunu düşünmüyorum. Şöyle açıklamak istiyorum. Kazanımlardan biri "+lIk, $+l U k$ " ekini ögrenir. Bununla ilgili kitapta hiçbir etkinlik bulunmamaktadır. Öğrencileri tek tip sinavlarla değerlendirmek yerine ders süresince gözlemlemek, ne kadar ilerlediğini görmek daha doğru bir değerlendirme olacaktır. Bu yüzden öğrencileri her beceri için birer veya daha fazla etkinlikle değerlendirerek onların gelişimlerini ya da hangi yönlerinin eksik olduğunu anlayabiliriz.

Tablo 7. Kültür aktarımı açısından ders araç-gereçleri ve materyallere yönelik katılımcı görüşleri

\section{Kültür aktarımı}

Ders kitapları

\section{f}

Olumlu Olumsuz Toplam

1

7 


\begin{tabular}{lccc}
\hline Kültür aktarımı & & f & Toplam \\
\hline Kültürel uyum & Olumlu & Olumsuz & 6 \\
Metinler & 1 & 5 & 7 \\
Görsel kullanımı & - & 7 & 4 \\
Gelenekler & 1 & 3 & 4 \\
Dil-kültür ilişkisi & 2 & 2 & 4 \\
Teknoloji kullanımı & 4 & - & 3 \\
Oyun merkezli öğretim & 1 & 2 & 1 \\
Kültürel geziler & 1 & - & 1 \\
Spor etkinlikleri & - & 1 & 1 \\
Yakından uzağa ilkesi & 1 & - & 1 \\
Halk edebiyatı unsurları & 1 & - & 1 \\
Coğrafi özellikler & - & 1 & 1 \\
Müzik & - & 1 & $\mathbf{4 3}$ \\
Toplam & $\mathbf{1 4}$ & - & $\mathbf{2 9}$ \\
\hline
\end{tabular}

Katılımcılar; kültür aktarımına yönelik kodların, motiflerin son derece fazla olmasına rağmen verilerin düzensiz ve yetersiz şekilde ders kitapları ile programa yerleştirildiğinden; özellikle kaynak kültürle uyumsuz motiflere, eylemlere ders araç ve gereçlerinde yer verilmesinden, ders kitaplarının bu yönüyle zengin bir içeriğe sahip olmamasından yakınmıştır. Özellikle hedef kültüre ait geleneklerin aktarılmasında teknolojik olanaklardan yeterince yararlanılmadığ aktarımlar yapılarak çözüm arandığı, iki kültür arasındaki uyumsuzlukların, çatışmaların öğretim sürecinde belirleyici olduğu ifade edilmiştir. Ders kitaplarındaki metinlerin bu açıdan son derece niteliksiz olduğu ifade edilmiştir. Çözüm önerisi olarak materyallerde kültürel kodlara daha fazla yer verilmesinin yararlı olacağı, yine öğretmen faktörünün son derece belirleyici olduğu, sistematik uygulama ve etkinliklere başvurulması gerektiği, bunda da yakından uzağa ilkesinin gözetilmesi gerektiği belirtilmiştir. Amaca yönelik görsel ve teknoloji kullanımının son derece destekleyici olduğu, kültür aktarımında gerçekçi bir bakış açısı geliştirmek ve kaynak kültürü küçümseyen kültür bombardımanından uzak durmak gerektiği dile getirilmiştir. Yine enstrüman çalmanın, Türk müziğinden yararlanmanın öğrencilerin dikkatlerini ve ilgilerini derslere yönlendirmede öğretmenlerin işlerini kolaylaştırdığından bahsedilmiştir. Bu konuda K3 ve K7’nin görüşleri aşağıda verilmiştir:

K-3: Kitapta kültüre ait pek öğenin bulunduğunu sanmıyorum. Türk kültürünü yansıtan tek şey Nasrettin Hoca ve Keloğlan resimlerinin bulunmasıydı. Metin bazında çok yetersiz. Her yaş seviyesine hitap etmesine olanak yok. Aylarca yalnızca kitaba baksak haram lokma yemiș olacaktık. Kültürel kodların aktarımı diyaloglarla ve görsellerle aktarılır. Bunun için ilgi çekici metin kitaplarda yer almalı, klasik bilgiler terk edilmelidir. Mesela, bayram ziyareti düz bir anlatımla değil, eğlenceli oyunlarla anlatılmalıdır. Bu bakımdan kitap, kılavuz kimliğine sahip olmalıdır. Kültürel özellikler anlatılmalıdır. Fakat bu özellikler anlatılırken empoze edilecek şekilde değil de onların kültürlerinin farklılıkları şeklinde anlatılmalıdır.

K-7: Hazırladığım materyalleri bizim kültürümüzü aktararak ve onların kültürünü de göz önünde bulundurarak hazırlıyorum. Ama bu durumda çok zorlanıyorum. Hedef kitlenin kültürü bizimkinden farklı olduğu için bazen bu kodu aktarırken büyük sorunlarla karşılaşıyorum. Öğrencilere kitaptaki kültürel kodun dışında yaşadığı ilin kültürel kodundan bahsederek, yani yakından uzağa ilkesini göz önünde bulundurarak kodu aktarmaya önem veriyorum. Kültür 
aktarımında kullanılan materyaller çok özenle seçilmelidir. Kullanılan araç-gereçlerin doğru bir şekilde yerel ve evrensel özellikleri yansıtması gerekir.

Tablo 8. Çoklu öğrenme ortamı sağlayabilmesi açısından ders araç-gereçleri ve materyallere yönelik katılımcı görüssleri

\begin{tabular}{|c|c|c|c|}
\hline \multirow{2}{*}{ Çoklu öğrenme ortamı } & \multicolumn{3}{|c|}{$\mathbf{f}$} \\
\hline & Olumlu & Olumsuz & Toplam \\
\hline Çoklu öğrenme & 4 & 6 & 10 \\
\hline Teknoloji kullanımı & 1 & 6 & 7 \\
\hline Çoklu zekâ kuramı & - & 2 & 2 \\
\hline Drama & 2 & - & 2 \\
\hline Nesne kullanımı & - & 1 & 1 \\
\hline İşbirlikçi öğrenme & - & 1 & 1 \\
\hline İlgi çekicilik & 1 & - & 1 \\
\hline Oyun merkezli öğrenme & 1 & - & 1 \\
\hline Kalıcı öğrenme & 1 & - & 1 \\
\hline Müzik & 1 & - & 1 \\
\hline Görsel kullanımı & 1 & - & 1 \\
\hline Tam öğrenme & 1 & - & 1 \\
\hline Toplam & 13 & 16 & 29 \\
\hline
\end{tabular}

Katılımcılar; teknolojik yetersizliklerden dolayı nesne kullanma zorunluluğu oluşmasından ve bu nedenle de kalıcı öğrenmeler gerçekleşmesinin zorlaştığından yakınmışlardır. Ders araç-gereçleri ile materyallerin birden fazla duyu organına hitap etmediği ve bu nedenle derslerin sıkıcı olduğu dile getirilmiştir. Ders kitaplarının çoklu öğrenme ortamlarını sağlayabilmesi ve desteklemesi noktasında son derece yetersiz olduğu dile getirilmiştir. Bu noktada yayın desteğine, internet tabanlı ortak bir platforma, çoklu zekâ kuramına dayalı uygulamalar ile materyallere; taklit, drama uygulamaları ve nesne kullanımına, derslerin öğrencilerin ilgisini çekecek şekilde eğlenceli hâle dönüştürülmesine, temel dil becerilerinin bütünleşik şekilde geliştirilmesine, öğretim süreçlerinde başta müzik olmak üzere sanat uygulamalarına yer verilmesine ihtiyaç duyulduğu belirtilmiştir. Bu konuya ilişkin K4 ve K5’in görüşlerine yer verilmiştir:

K-4: Kullandığım araç ve gereçler çoklu öğrenme ortamı sağlayabilmesi noktasında eksik kalıyor. Yeterli değil. Sinıfların kalabalık olması sebebiyle yeterli düzeyde çoklu öğrenme ortamı sağlanamamaktadır. Materyallerin tek boyutlu olması, teknolojik desteğin yetersiz olması, çok kalabalık sınıflarda ders işlenmesi çoklu öğrenme ortamını engellemektedir.

K-5: Projeksiyon olmadığı için çoklu öğrenme ortamı biraz sıkıntı oluyor. Telefon veya bilgisayar kullanabildiğim çalışmalarda bunu sağlayabiliyorum. Ancak her etkinlik bunlarla yapılamayabiliyor, bu durumda bir eksiklik oluyor. Bu imkânların olması işimizi hem daha kolaylaştırırdı hem de öğrenmeyi hızlandırırdı. Elimizdeki imkânlarla bunu sağlamaya çalıșıyoruz. Ders araç gereçlerinin çoklu öğrenme ortamı sağlaması açısından farklı yöntem ve teknikleri uygulayabilmesine ortam hazırlamalıdır. Bu noktada eksik kaldığımı söylemek zorundaydım.

Tablo 9. Öğretmenin materyal hazırlama hâkimiyetleri açısından katılımcı görüşleri

Materyal hazırlamaya hâkimiyet

\section{f}

Olumlu
Toplam 


\begin{tabular}{|c|c|c|c|}
\hline \multirow{2}{*}{ Materyal hazırlamaya hâkimiyet } & \multicolumn{3}{|c|}{$\mathbf{f}$} \\
\hline & Olumlu & Olumsuz & Toplam \\
\hline Bilinenden bilinmeyene ilkesi & 5 & - & 5 \\
\hline Çocuğa görelik & 5 & - & 5 \\
\hline Tecrübe & - & 4 & 4 \\
\hline Amaç birlikteliği & 3 & - & 3 \\
\hline Anlamlılık & 3 & - & 3 \\
\hline Akademik özyeterlik & 2 & 1 & 3 \\
\hline Dikkat çekicilik & 3 & - & 3 \\
\hline Hazır materyal & - & 2 & 2 \\
\hline Hayatîlik & 2 & - & 2 \\
\hline Eğitim ihtiyacı & 1 & 1 & 2 \\
\hline Teknoloji kullanımı & 1 & - & 1 \\
\hline Alan yazın takibi & 1 & - & 1 \\
\hline Örnek çeşitliliği & 1 & - & 1 \\
\hline Bireysel farklılıklar & 1 & - & 1 \\
\hline Ekonomiklik & 1 & - & 1 \\
\hline Çoklu öğrenme & 1 & - & 1 \\
\hline 3 boyutluluk & - & 1 & 1 \\
\hline Toplam & 36 & 9 & 45 \\
\hline
\end{tabular}

Katılımcllar; materyal hazırlayabilme noktasında tecrübe eksikliğine, bu konuda yeterli eğitim almamış olmalarına dikkat çekmişlerdir. Bir diğer katılımcı ise öğretmenliğin içgüdüsel olarak gerçekleştirilebileceğini belirtmiş, mesleki yeterlilik ve bu konudaki eğitimin çok da belirleyici olmadığını dile getirmiştir. Yine ekonomik ve zamanda tasarruf sağlayacak materyaller geliştirilmesine özen göstermeye çalıştıklarını belirtmişlerdir. Akademik özyeterlikleri noktasında da kendilerini yetersiz gören katılımcılar, bu noktada hazır materyalleri kendi amaçları doğrultusunda uyarlama yoluna başvurduklarını; ayrıca Suriyelilerin özelliklerinden dolayı zorlandıklarını dile getirmişlerdir. Her ne kadar katılımcıların çoğu materyal hazırlama ilkelerine dikkat etmeye çalışmışsalar da tecrübe eksikliğinin olumsuz yansımalarını yaşadıklarını söylemişlerdir. Yine malzeme temini noktasında sıkıntılarının olduğunu ifade etmişlerdir. Basitlik ve bilinenden başlama ilkelerine dikkat etmeye çalıştıklarını söyleyen katılımcılar; başta kitaplar ve internet ortamındaki yayınlar olmak üzere alan yazını takip etmeye çalıştıklarını dile getirmişlerdir. Yine geliştirilen materyallerin tekrar tekrar kullanılabilmesine özen gösterdiklerini, görselleri etkili şekilde kullanmaya çalıştıklarını, zamanla tecrübe kazanacaklarını, öğrenci merkezli materyaller hazırlanması gerektiğini, zorlukların öğretmenlerin özverili çalışmaları ile aşlabileceğini, öğrencilerin günlük hayattaki ihtiyaçlarına yönelik bilgi ve becerilere öncelik verilmesi gerektiğine, çoklu öğrenmeleri mümkün kılan ders araçgereçleri ile materyallerin daha etkili olduğu/olacağına yönelik görüşler dikkat çekicidir. Bu hususta katılımcılardan K1 ve K5, görüşlerini şöyle ifade etmişlerdir:

K-1: Ben altı aydır yabancı dil eğitimi alanında görev yapıyorum. Deneme yanılma ile bir şeyler öğrenmeye çalışıyoruz. Bu konuda detaylı bir eğitim almamız gerektiğine inanıyorum. Yaş gurubu olarak ilkokul düzeyine hitap edebilmek için materyalleri oluştururken daha çok basitlik ve bilinenden başlama ilkesine dikkat ediyorum.

K-5: Tam olarak yeterli olabildiğimi düşünmüyorum. Daha çok ve öncelikli olarak hazır materyalleri kullanıyorum. Eğer uygun bulamazsam, işe yarar yoksa kendim hazırlama ve ya uyarlama yoluna 
gidiyorum. Bir materyalin nasıl olması gerektiğini bazen sınıfımdaki öğrencilerden yola çıkarak yaparım. Yaptığım bir materyali beğenmeyebiliyorlar. Bu yüzden elimden geldiğince onları katarım duruma. Materyal hazırlamada anlamlılığa, bilinenden bilinmeyene olmasına dikkat ediyorum. İlkokulda olduğum için bu ilkeleri çok önemsiyorum. Türk okullarında bunu uygulamak daha kolay olmakta. Ama Suriyelilerde görelik kavramı daha da basitleştirmeye çabalıyorum.

\section{Tartışma ve sonuç}

Suriyelilere Türkçe öğreten öğretmenlerin materyal hazırlama, geliştirme ve kullanma durumlarını incelemeyi amaçlayan bu çalışmada öğretmenlerin görüşlerine başvurulmuştur. Çalışma kapsamda öğrencilerin materyallere ilişkin hazır bulunuşluk düzeyleri, materyallerin öğretim ilkelerine, temel iletişim becerilerine, öğretmen veya öğrenci merkezliliğe, ölçme ve değerlendirmeye, kültür aktarımına, çoklu öğrenme ortamına uygunluğu ve öğretmenlerin materyal hazırlama hâkimiyetleri incelenmiştir. Öğrencilerin materyallere ilişkin hazır bulunuşluk düzeyiyle ilgili bulgulara bakıldığında bilgi düzeyleri, sosyokültürel yapı, bireysel farklar, öğrenme hızı, motivasyon gibi hususlarda olumsuz durumlar yaşadıkları belirtilmiştir. Genel olarak bakıldığında öğrencilerin materyallere ilişkin hazır bulunuşluk düzeylerinde ciddi sıkıntıların olduğu görülmektedir. Çeşitli sebepleri olan bu durumun öğrenme ortamını olumsuz etkilemesi yönüyle düzeltilmesi gereken bir husus olduğu anlaşılmaktadır. Özdemir'e (2013) göre öğrencilerin sahip oldukları bireysel farklılıklar ve hazır bulunuşluk düzeyleri, kendilerine yöneltilen bilgileri algılama kapasitelerini önemli ölçüde etkilemektedir. Akpınar Dellal ve Seyhan Yücel'e (2015) göre öğretmenler, öğrenci ilgisi ve seviyesine uygun olan yaratıcı materyal tasarlamakta belli ölçüde sıkıntı yaşamaktadırlar. Bu durum da öğrencinin özelliklerine uygun olmayan materyallerin üretimine neden olmaktadır. Biçer ve Kılıç (2017) tarafından yapılan çalışmada da Suriyeli öğrencilerin Türkçe ders kitaplarının öğrenci seviyesine, ilgi ve ihtiyaçlarına uygun olmadığ belirtilmiştir. Kullanılan materyallerin öğrencilerin hazır bulunuşluk düzeyine uygun olmadığı yönündeki bu çalışmalar da bu hususta dikkate değerdir.

Materyallerin temel öğretim ilkelerine uygunluğuna bakıldığında genel öğretim ilkelerine, basitten zora, bilgiyi somutlaştırma gibi ilkelerde olumlu değerlendirmeler yapıldı̆̆ı anlaşılmaktadır. Bazı ilkeler açısından eksiklikler bulunmasına rağmen materyallerin öğretim ilkelerine uygun olduğu yaygın kanaattir. Materyallerin eksik olan bazı yönlerinin öğretmenlerin müdahalesiyle giderilmesi mümkündür.

Materyallerin temel iletişim becerilerine uygunluğuna bakıldığında teknolojik eksikliklerden dolayı bazı becerilerin gelişmediği, dinleme becerisinde yetersizlikler olduğu gibi hususlar öne çıkmaktadır. Diğer boyutlar da değerlendirildiğinde temel iletişim becerilerini kazandırmada materyallerin ciddi eksikliklerinin bulunduğu belirtilmiştir. Türkçe dersinin temel dayanağı olan bu becerilerin kazanımında ortaya çıkacak problemler, verilen eğitimin anlamsız hâle gelmesine sebebiyet verebilir. Bu sebeple dilin iletişimsel boyutu ön planda tutularak öğretim elemanlarının kendi materyallerini hazırlamaları (Şengül, 2015) gerekir. Kılınç ve Yenen (2015) dinleme etkinliklerinin interaktif CD'lerle desteklenmesi ve konuşmayı teşvik edici etkinliklerin arttırılması gerektiğini ifade etmişlerdir.

Öğretmen veya öğrenci merkezlilik açısından ders materyalleri değerlendirildiğinde öğretmen faktörünün önemli görüldüğ̈̈, öğrenci merkezlilik, yaparak öğrenme, öğretmen merkezlilik gibi hususlar başta olmak üzere birçok konuda olumsuz düşüncelerin öne çıtı̆̆g görülmektedir. Özellikle, öğrencinin öğrenme sürecine katılımını artıracak öğrenci merkezli uygulamaların gerekli olduğu belirtilmesine rağmen materyallerin bunu sağlamada yeterli olmadığ 1 ifade edilmiştir. Bu durumun gerçekleşmesi için öğrencilerin yapmaktan zevk alacakları, oyuna dayalı, görsellerle desteklenmiş 
eğitim materyallerinin sınıftaki önemi büyüktür. Bazı katılımcılar sınıfta öğretmen merkezli aktivitelerin daha yararlı olduğunu dile getirmişlerdir.

Materyallerin ölçme ve değerlendirmeye uygunluğu incelendiğinde geleneksel ölçme ve değerlendirmeye yönelimin olduğu, standart ölçme ve değerlendirme araçlarının azlığı ve öğretmenlerin ölçme ve değerlendirme konusunda donanım eksikliğinin sorun yarattığı ifade edilmektedir. Ders kitaplarında bulunan ölçme ve değerlendirme kısımlarının yetersiz olduğu ve öğretmenlerin ana dili öğretiminde kullanılan araçları uyarlama eğiliminde oldukları belirtilmektedir. Ölçme ve değerlendirme gibi uzmanlık gerektiren bu hususlarda öğretmenlerin dışında bazı standart ölçme araçlarının bulunması gerekir.

Materyallerin kültür aktarımına uygunluğu durumuna bakıldığında Türk kültürüne yönelik ögelerin ders kitaplarına uygun yerleştirilmediği ve bu anlamda eksikliğin olduğu ifade edilmiştir. Kültür aktarımında teknolojik araç ve gereçlerden yeterince istifade edilmediği, metinlerin kültürel kodları taşımadığını ve niteliksiz olduğu belirtilmiştir. Görüşlerin öğretim sürecindeki materyallerin kültür aktarımı hususunda birçok eksiklik barındırdığı ve öğrencilere bu ögeleri kazandırmak noktasında yetersiz kaldığı yönünde yoğunlaşmaktadır. Sınıf içi öğretimde yoğun bir kullanım oranına sahip olan ders kitaplarının kültür aktarımında da önemli bir rol üstlendiği anlaşılmaktadır. Demir'e (2015) göre yabancllara Türkçe öğretiminde kullanılacak ders kitaplarındaki metinler, Türk kültürünün özelliklerini olumlu yönde ve en güzel biçimde yansıtabilmelidir. Akpınar Dellal ve Seyhan Yücel'e (2015) göre kültür aktarımı, kültürlerarası karşılaştırma, konu çeşitliliği ve zenginliği açısından yabancı dil öğrenim sürecinde ders kitapları dışında farklı materyallere ihtiyaç duyulmaktadır. Özellikle teknolojik materyallerin farklı duyu organlarını harekete geçirici özelliği dikkate alındığında kültür aktarımında etkin kullanımları sağlanabilir.

Çoklu öğrenme ortamının sağlanmasında materyallerin etkisi önemlidir. Bu çerçevede katılımcıların görüşleri incelendiğinde kullanılan materyallerin tekdüze olduğu ve farklı duyu organlarını harekete geçirici nitelikte olmadığı anlaşılmaktadır. Öğretmenlerin bu sorunu aşmak için drama, oyunlar, görseller ve nesneleri kullandıkları belirtilmiştir. Yapılan bu etkinliklerin öğrencilerin kalıcı öğrenmesine katkı sağladığı düşünülmektedir. Akpınar Dellal ve Seyhan Yücel'in (2015) araştırmasında materyal kullanımının kalıcı öğrenmeye yardımcı olduğu ve öğrencileri motive ettiği belirtilmektedir. Yabancı dil öğretiminde öğrencilerin öğrenme stilleri göz önünde bulundurularak materyal hazırlamasının önemli olduğu ifade edilir. Böylece çoklu öğrenme ortamı sağlanarak etkin ve kalıcı öğretim sağlanmış olur. Yanpar Yelken (2009: 86) de özellikle öğretmenler tarafından geliştirilen materyallerin öğrenmenin kalıcılı̆̆ını ve öğrenci motivasyonunu artırdığını ifade eder. Şengül (2015) materyallerin anlamayı sağladığı, öğretimi hızlandırdığı, öğretim sürecini sevdirdiği, kolaylık sağladığı, dikkat çektiği ve verimli olduğu yönünde bazı bulgulara ulaşarak materyallerin öğrenme ortamını önemli oranda nitelikli hâle getirdiğini belirtir. Bulguları destekleyecek şekilde Kurtdede Fidan (2008) da materyalle yapılan öğretimin, çocuklarda kalıcı öğrenmeyi sağladığı, öğrencilerin derse karşı ilgilerini artırdığı, onların eğlenerek öğrenmelerini sağladığı, aktif katılım sağladığı, öğrenilen bilgilerin günlük hayata transferinin olduğu yönünde bazı sonuçlar elde etmiştir.

Öğretmenlerin materyal hazırlama hâkimiyetleri ve becerileri açısından incelendiğinde basitlik ilkesi, bilinenden bilinmeyene ilkesi, çocuğa görelik, anlamlılık, dikkat çekicilik gibi unsurlara dikkat edilerek materyal hazırlamaya çalıştıkları ifade edilmiştir. Bununla birlikte tecrübe eksikliği yaşamalarından ötürü bazı sorunlarla karşılaştıkları belirtilmiştir. Öğretmenlerin materyal hazırlama becerilerinde bazı aksaklıklar yaşansa da genel olarak öğrencilerin etkili öğrenmesi için materyaller geliştirdikleri veya 
uyarladıkları görülmektedir. Öğretmenlerin materyallerde olması gereken bu ilkelerin farkında olması ve bunu kullanmaları önemli bir adım olarak düşünülmelidir. Çalışmanın sonuçlarıyla uyumlu bir şekilde öğretmenlerin materyal hazırlama ve kullanma konusunda olumlu görüșe sahip oldukları Namlu (1998), Karamustafaoğlu ve diğerleri, 2012; Karamustafaoğlu, 2006; Mete ve Gürsoy, 2013 tarafından da ifade edilmektedir. Bunun yanında öğretmenlerin materyal konusunda özellikle ekonomik ve alt yapıdan kaynaklanan sebeplerle problemler yaşadığı Mete ve Gürsoy, 2013; Şengül, 2015; Akpınar Dellal ve Seyhan Yücel, 2015; Kurtdede Fidan, 2008; Korkmaz, 2018 tarafından da dile getirilmiştir. Materyal konusunda yaşanan sorunların dile getirilmesi öğretmenin hedef kitle profiline uygun materyal seçme veya seçilmiş materyali uyarlama becerisine sahip olma gerekliliği ve bu konularda eğitim almaları gerektiği şeklinde yorumlanabilir (Mete ve Gürsoy, 2013). Birçok alanda olduğu gibi Türkçe öğretimini gerçekleştiren öğretmenler de bu sorun varlığını hissettirmektedir. Suriyeli öğrencilerin eğitim kurumlarının alt yapı durumları düşünüldüğünde normal okullara göre daha fazla eksikliğinin olduğu ve bunun materyal konusunda da daha fazla dezavantaj yarattığı söylenebilir.

Çalışmanın sonuçları değerlendirildiğinde öğrencinin ve öğretmenin olumlu düşüncelerine karşılık süreçte önemli eksikliklerinin olduğu belirlenmiștir. Bu konuda araştırmacılara, öğretmenlere ve kurumlara önemli görevler düşmektedir. Öğretmenlerin eğitiminde uygulamalı bazı dersler/kursların olması materyal hazırlama becerilerini artıracaktır. Materyal ve ders kitabı hazırlayıcıların hedef kitlenin özelliklerini gözeterek materyaller hazırlamaları gerekir. Türkçe öğretimi alanında materyal çeşitliliğinin artması da sürece katkılar sağlayacaktır. Bu konuda çalışan araştırmacıların materyallerin farklı öğrenci grupları veya dil becerilerine etkisi üzerine çalışmalar yapmaları alana ve öğretmenlere yol gösterecektir.

\section{Kaynakça}

Akpınar Dellal N. ve Seyhan Yücel M. (2015). Yabancı dil öğretmenlerinin derslerinde materyal kullanımına ilişkin tutum ve görüsleri. Turkish Studies International Periodical For The Languages, Literature and History of Turkish or Turkic, 10(2), 1051-1066. http://dx.doi.org/10.7827/TurkishStudies.7950.

Altıparmak, H. M. ve Özcan, Ş. (2016). Türkçenin yabancı dil olarak öğretiminde temel yaşam alanlarından hareketle bilgisayar destekli bir kaynak önerisi: Görsel senaryo. Mustafa Kemal Üniversitesi Sosyal Bilimler Enstitüsü Dergisi, 13(34), 68-77.

Artuç, S. (2013). Türkçenin yabancı dil olarak öğretiminde bilişimden yararlanma: paragraf çalışmaları. International Journal of Language Education and Teaching, 1, 80-91.

Baki, Y. ve Karakuş, N. (2012). Türkçe öğretiminde öğretim teknolojileri ve materyal tasarımı. Ankara: Pegem Akademi Yayınları.

Barın, E. (2004). Yabancllara Türkçe öğretiminde ilkeler. Hacettepe Üniversitesi Türkiyat Araştırmaları (HÜTAD), 1, 19-30.

Bektaş, F., Nalçacı, A. ve Ercoşkun, H. (2009). Sınıf öğretmeni adaylarının "öğretim teknolojileri ve materyal geliştirme/tasarımı” dersinin kazanımlarına ilişkin görüşleri. Kuramsal Eğitimbilim, 2(2), 19-31.

Biçer, N. (2016). An evaluation of pre-service Turkish teachers' skills and knowledge regarding preparation of worksheets to teaching Turkish to foreigners. Educational Research and Reviews, 11(5), 164-173. http://dx.doi.org/10.5897/ERR2015.2549.

Biçer, N. ve Kılıç, B. S. (2017). Suriyeli öğrencilere Türkçe öğretmek için kullanılan ders kitaplarının öğretmen görüşleri doğrultusunda değerlendirilmesi. Ana Dili Ĕğitimi Dergisi, 5(4), 649-663. http://dx.doi.org/10.16916/aded.329809.

Bilgin, N. (2014). Sosyal bilimlerde içerik analizi: teknikler ve örnek çalş̧malar. Ankara: Siyasal Kitabevi. 
Büyüköztürk, Ş., Çakmak, E. K., Akgün, Ö. E., Karadeniz, Ş. ve Demirel, F. (2014). Bilimsel araştırma yöntemleri. Ankara: Pegem Akademi Yayınları.

Creswell, J. W. (2016a). Araştırma deseni: nitel, nicel ve karma yöntem yaklaşımları. Çev., Ed., Selçuk Beşir Demir. Ankara: Eğiten Kitap.

Creswell, J. W. (2016b). Nitel araştırma yöntemleri: beş yaklaşıma göre nitel araştırma yöntemleri. Çev., Ed., Mesut Bütün ve Selçuk Beşir Demir. Ankara: Siyasal Kitabevi.

Creswell, J. W. ve Plano Clark V. L. (2015). Karma yöntem araştırmaları: tasarımı ve yürütülmesi. Çev., Ed., Yüksel Dede ve Selçuk Beşir Demir. Ankara: Anı Yayıncılık.

Demir, T. (2015). Yabancı dil olarak Türkçe öğretiminde materyal yetkinliği -ders kitapları. Dil Dergisi, 166(1), 43-52.

Demirel, Ö. (1990). Yabancı dil öğretimi, ilkeler, yöntemler, teknikler. Ankara: USEM Yayınları.

Doğan, Y. (2014). Yabancılara Türkçe kelime öğretiminde market broşürlerinden yararlanma. Journal of Language and Linguistic Studies, 10(1), 89-98.

Duman, G. B. (2013). Türkçenin yabancı dil olarak öğretiminde materyal geliştirme ve materyallerin etkin kullanımı. Ana Dili Ĕ̆itimi Dergisi, 1(2), 1-8.

Dursun, F. (2006). Öğretim sürecinde araç kullanımı. İlköğretmen Dergisi, 1, 8-9.

Fries, C. C. (1959). Preparation of teaching materials, practical grammars, and dictionaries, especially for foreign languages. Proceedings of the Eighth International Congress of Linguists. Oslo University Press, 738-746.1.

Fuller, G. E. (2001). Yabancı dil nasıl öğrenilir? İstanbul: Avesta Basın Yayın.

Haciömeroğlu, M. S. (2007). Yabancı dil olarak Türkçe öğrenenler için kiplik öğretimi üzerine materyal geliştirme. Yayınlanmamış Yüksek Lisans Tezi, Dokuz Eylül Üniversitesi, İzmir.

Halis, İ. (2001). Öğretim teknolojileri ve materyal geliştirme. Konya: Mikro Yayınları.

Heinich, R., Molenda, M. ve Russell, J. D. (1993). Instructional media and the new technologies of instruction (4th. Ed.). NY: Macmillan Publishing Company, England.

Ilgar, M. (2013). Yabancı Dil Olarak Türkçe öğretiminde e-öğrenim yoluyla kelime öğretimi. Yayınlanmamış Yüksek Lisans Tezi, Gazi Üniversitesi, Ankara.

Kanğ, S. (2015). Yabancı dil olarak Türkçe kelime öğretiminde eğitim teknolojilerini kullanma. Dede Korkut Dergisi, 7, 73-84.

Karamustafaoğlu, O. (2006). Fen ve teknoloji öğretmenlerinin öğretim materyallerini kullanma düzeyleri: Amasya ili örneği. A ̈Ü. Bayburt Eğitim Fakültesi Dergisi, 1(1), 90-101.

Karamustafaoğlu, O., Çakır, R. ve Topuz, F. (2012). Fen öğretiminde öğretmenlerin derslerinde materyal ve teknoloji kullanimına yönelik tutumlarmin incelenmesi. X. Ulusal Fen Bilimleri ve Matematik Eğitimi Kongresi, Niğde: Niğde Üniversitesi.

Karasar, N. (2009). Bilimsel araştırma yöntemi. Ankara: Nobel Yayıncılık.

Kaya, Z. (2006). Öğretim teknolojileri ve materyal geliştirme. Ankara: Pegem Yayınları.

Kılınç, H. H. ve Yenen, E. T. (2015). Yabancılara Türkçe öğretiminde kullanılan ders kitaplarına ilișkin öğretim elemanlarının görüssleri. International Journal of Language Academy, 3(4), 429-441. http://dx.doi.org/10.18033/ijla.288.

Korkmaz, M. (2018). İmam hatip meslek dersleri öğretmenlerinin materyal geliştirme durumları. Bilimname, 1, 175-216. http://dx.doi.org/10.28949/bilimname.380607.

Kurtdede F. N. (2008). İlköğretimde araç gereç kullanımına ilişkin öğretmen görüşleri. Kuramsal Ĕ̆itimbilim, 1(1), 48-61.

Mete, F. ve Gürsoy, Ü. (2013). Yabancı dil olarak Türkçe öğretiminde öğretmen yeterliklerine ilişkin görüşler. Hacettepe Üniversitesi Eğitim Fakültesi Dergisi, 28(3), 343-356. 
Miles, M. B. ve Huberman, A. M. (2016). Genişletilmiş bir kaynak kitap: nitel veri analizi. Çev., Sadegül Akbaba Altun ve Ali Ersoy. Ankara: Pegem Akademi.

Namlu, A. G. (1998). Öğretmenlerin eğitimde teknoloji yönelik tutumları. Anadolu Üniversitesi Eğitim Fakültesi Dergisi, 8(1-2), 184-200.

Önal, H. vd. (2017). Sosyal bilgiler öğretmen adaylarının etkinlik yaptırma ve materyal kullanımına yatkınlıkları. Academia Eğitim Araştırmaları Dergisi, 2(2), 11-19.

Özdemir, C. (2013). Yabancılara Türkçe öğretiminde ders malzemelerinin önemi ve işlevsel ders $\begin{array}{llll}\text { malzemelerinin nitelikleri. } & \text { Turkish } & \text { Studies, } & \text { 8(1), }\end{array}$ http://dx.doi.org/10.7827/TurkishStudies.4495.

Özer, Ö. ve Tunca, N. (2014). Öğretmen adaylarının materyal hazırlama ve kullanmaya yönelik görüşleri. RessJournal, 1(3), 214-229.

Patton, M. Q. (2014). Nitel araştırma ve değerlendirme yöntemleri. Çev., Mesut Bütün ve Selçuk Beşir Demir. Ankara: Pegem Akademi.

Sönmez, V. ve Alacapınar, F. G. (2016). Sosyal bilimlerde ölçme aracı hazırlama. Ankara: Anı Yayincillk.

Sülükçü, Y. (2011). Yabancllara Türkçe Öğretiminde (Temel Seviye A1) bilgisayar destekli materyal geliştirme ve bunun öğrenci başarısına etkisi. Yayımlanmamış doktora tezi, Selçuk Üniversitesi Eğitim Bilimleri Enstitüsü, Konya.

Şad, N. ve Arıbaş, S. (2008). Kuramına dayalı materyal ve etkinlik kullanma düzeyleri (Malatya ili örneği). İnönü Üniversitesi Eğitim Fakültesi Dergisi, 9(15), 169-187.

Şahin, S. ve Gençtürk, E. (2007). Coğrafya eğitimi ve bilgi iletişim teknolojileri. Ed., Servet Karabă̆. Kuram ve Uygulamada Coğrafya Eğitimi. Ankara: Gazi Kitapevi.

Şen, Ü. (2015). Yurt dışında yaşayan Türk çocuklarına Türkçe öğretimi ve materyal tasarmı (Belçika örneği). Ankara: Edge Akademi Yayınları.

Şengül, K. (2015). Öğretim elemanlarının yabancılara Türkçe öğretiminde kullanılan materyallere ilişkin görüşleri. Researcher: Social Science Studies, 3(2), 14-25. http://dx.doi.org/10.7827/TurkishStudies.7134.

Tarakcığlu, A. Ö. (2012). Yabancı dil öğretiminde materyal geliştirme, uyarlama ve kullanımının önemi. Ed., Arif Sarıçoban ve Zekiye Müge Tavil. Yabancı Dil Öğretiminde Öğretim Teknolojileri ve Materyal Tasarmı (1-18). Ankara: Anı Yayıncılık.

Taşköprü, G. (2017). Yabancı dil olarak Türkçe sınıflarında konuşma becerisini geliştirmeye yönelik materyal hazırlama. Yayınlanmamış Yüksek Lisans Tezi, Dokuz Eylül Üniversitesi Eğitim Bilimleri Enstitüsü, İzmir.

Tor, H., ve Erden, O. (2004). İlköğretim öğrencilerinin bilgi teknolojilerinden yararlanma düzeyleri üzerine bir araştırma. Turkish Online Journal of Educational Technology, 3(1), 120-130.

Türnüklü, A. (2000). Eğitimbilim araştırmalarında etkin olarak kullanılabilecek nitel bir araştırma tekniği: görüşme. Kuram ve Uygulamada Eğitim Yönetimi, 24, 543-559.

Yalın, H. İ. (2003). Öğretim teknolojileri ve materyal geliştirme. Ankara: Nobel Yayınları.

Yanpar Yelken, T. (2009). Öğretmen Adaylarının portfolyoları üzerinde grup olarak yaratıcılık temelli materyal geliştirmenin etkileri. Eğitim ve Bilim, 34(153), 83-98.

Yıldırım, A. ve Şimşek, H. (2005). Sosyal bilimlerde nitel araştırma yöntemleri. Ankara: Seçkin.

Yllmaz, F. ve Talas, Y. (2015). Yabancı dil olarak Türkçe öğretiminde materyal olarak animasyon kullanımı ve önemi. IJLET, 3(1), 114-127. 